\title{
ABNORMALITIES OF CARBOHYDRATE METABOLISM OF RED CELLS IN HEREDITARY SPHEROCYTOSIS 1, 2
}

\author{
By THOMAS A. J. PRANKERD, ${ }^{3}$ KURT I. ALTMAN, AND LAWRENCE E. YOUNG \\ (From the Departments of Medicine and Radiation Biology, the University of Rochester \\ School of Medicine and Dentistry, and the Medical Clinics of the \\ Strong Memorial Hospital, Rochester, N. Y.)
}

(Submitted for publication September 16, 1954; accepted April 6, 1955)

We have recently described a method for investigating glycolysis of red cells by using $\mathrm{P}^{\mathbf{3 2}}$ labeled orthophosphate to measure the rate of turnover of various organic phosphate esters (1). Observations on normal cells incubated under various conditions have been made with this method and described in separate reports $(2,3)$. Because inborn errors of metabolism have been demonstrated in a variety of hereditary diseases, this method has been applied especially to the study of red cells from patients with certain congenital hemolytic disorders. We have focused our attention particularly upon hereditary spherocytosis (to be abbreviated as HS) and will report results obtained from patients with this disorder in this paper. Our findings in other hemolytic states, both congenital and acquired, will be described later.

\section{METHODS}

The methods of estimating the rate of incorporation of radioactive orthophosphate into phosphate esters of the red cell have been described previously in detail (1, 2). Freshly drawn heparinized blood was incubated at $37.5^{\circ}$ C. with 0.05 to $0.15 \mathrm{ml}$. of $0.0007 \mathrm{~N} \mathrm{NaH} \mathrm{P}^{32} \mathrm{O}$, having approximately $10^{5}$ counts per minute (c.p.m.) and at appropriate intervals the phosphorus compounds were extracted with trichloracetic acid from samples of red cell stroma and from the remaining intracellular material. From these extracts the phosphoruscontaining compounds were isolated by paper chromatog-

1 These studies were aided by a contract between the Office of Naval Research, Department of the Navy, and the University of Rochester (NR 102-174) and by the David Smalline and Karl R. Schnepel Memorial Funds. This paper is based in part on work performed under contract with the U. S. Atomic Energy Commission at the University of Rochester Atomic Energy Project.

2 This report was presented in abbreviated form at the annual meeting of the American Society for Clinical Investigation, Atlantic City, New Jersey, May 3, 1954.

3 Traveling Fellow of the British Postgraduate Medical Federation, Present Address: University College Hospital, London W.C. 1. raphy, using the method of Caldwell (4), and the radioactivity and total concentration of phosphorus in each fraction were determined. In most cases estimates of relative specific activity (RSA) were made on samples taken after incubation for two and four hours, since equilibrium is not usually reached before six hours. In the course of other experiments in this laboratory we have found that the concentration of glucose in both normal and HS blood after four hours' incubation at body temperature varies from approximately $10 \mathrm{mg}$. to 30 $\mathrm{mg}$. per $100 \mathrm{ml}$. of blood and is sufficient to support cell metabolism. RSA as defined here refers to c.p.m. per $\mu \mathrm{g}$. $\mathrm{P}$ corrected to a standard addition of $10^{5}$ c.p.m. All values for the rate of $P^{32}$ exchange were corrected to a standard hematocrit of 40 per cent and a standard addition of $10^{5}$ c.p.m. per ml. plasma.

The hematocrit of venous blood was determined by the method of Wintrobe (5) and corrected for trapped intercellular plasma by using the graphs of Chaplin and Mollison (6). Chaplin and Mollison (6) and Furth (7) have found little difference between normal and HS cells with regard to trapped plasma after centrifugation in Wintrobe tubes, provided the blood was freshly drawn and the hematocrit was within the range encountered in this study (7). Methods of measuring osmotic and mechanical fragility of red cells in both freshly drawn and incubated defibrinated blood have been described elsewhere (8). Autohemolysis of red cells in sterile defibrinated blood during incubation at body temperature for 48 hours was measured by the method of Selwyn and Dacie (9) with minor modifications. Direct antiglobulin tests were made by the method of Evans and Duane (10).

\section{CLINICAL MATERIAL}

In Table I are listed pertinent clinical and hematologic data obtained in 18 cases of chronic spherocytosis. All of these patients showed the typical hematological findings of hereditary spherocytosis (8). The most important of these were: the presence of spherocytes in smears or wet preparations of peripheral blood, increased osmotic and mechanical fragility of the red cells with greater than normal increments in fragility after incubation of the blood for 24 hours at body temperature, marked spontaneous lysis of the red cells during incubation at body temperature for 48 hours, and inagglutinability of the red cells by antiglobulin serum (negative direct Coombs test). 
TABLE I

Clinical and hematologic data obtained in 18 cases of spherocytosis at time of studies on red cell metabolism

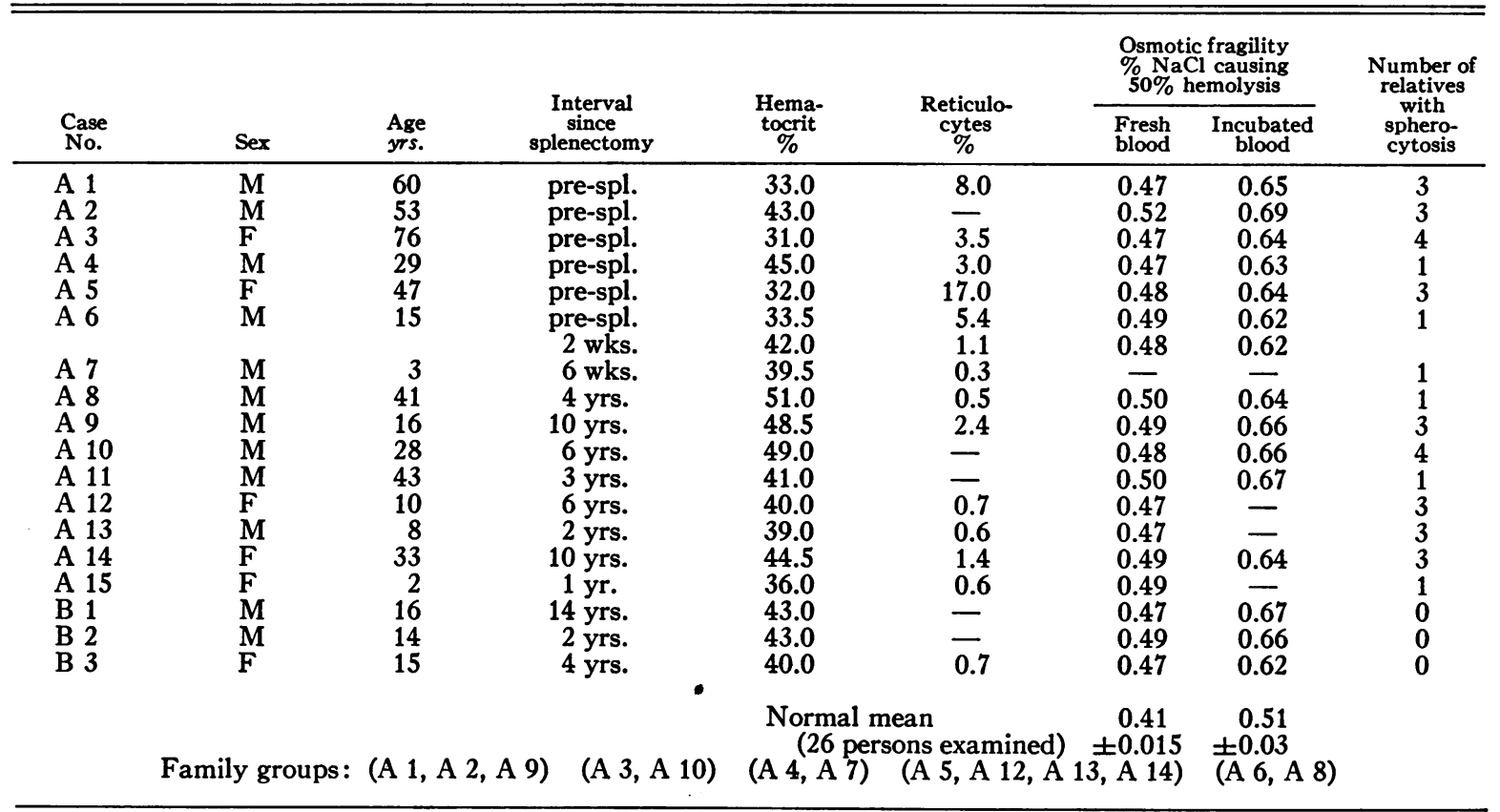

Hematologic abnormalities of the red cells were found to persist in the 13 splenectomized patients who were re-examined after intervals of from 2 weeks to 14 years following operation. Histological examination of the spleen in each of the 13 cases revealed findings in accord with a diagnosis of hereditary spherocytosis (11-13).

One or more relatives of each of the first 15 patients listed in Table I (group A) was shown unequivocally to have hematologic abnormalities typical of hereditary spherocytosis. No hematologic abnormality could be demonstrated in either parent or in any of the other available relatives of the last 3 patients listed in Table I (group B). None of these 3 patients has yet produced offspring. These and other atypical cases of chronic spherocytosis will be dealt with in detail in a separate paper. We have included the cases of group B in this report because the hematologic findings before and after splenectomy followed the same pattern as that of the 15 cases of group $\mathbf{A}$.

\section{RESULTS OF STUDIES ON RED CELL METABOLISM}

\section{Studies on normal red cells}

Under the conditions of these experiments (2) the exchange of $\mathrm{P}^{32}$ between plasma and red cells from hematologically normal persons was found to have a rate constant of $0.24 \pm 0.1 \mathrm{hr}^{-1}$. This constant represents the fall in plasma $\mathrm{P}^{32}$ in arbitrary units per hour, and is calculated from the standard equation for a first order process : $\mathrm{K}=$ $1 / t \ln \left(C_{o} / C_{t}\right)$. This is actually a composite constant representing the disappearance of $\mathrm{P}^{32}$ from the plasma and incorporation into cell esters (2). A constant interrelationship was demonstrated among the RSA of various intracellular phosphate esters (Figure 1), in that 2,3-diphosphoglycerate (2,3-DPG) had a higher RSA than adenosine triphosphate (ATP) ${ }^{4}$ and the RSA of these compounds exceeded that of inorganic phosphate (IP) except at the very beginning of incubation and at equilibrium $(1,2)$. The relation of the RSA of 2,3-DPG and ATP is compatible with the hypothesis that the former compound is a precursor of the latter. The two terminal P-atoms of ATP are known to contain most of the $\mathrm{P}^{32}$ activity of this compound and the phosphate attached to carbon atom 3 of 2,3-DPG has a very low activity as evidenced by measurements of the $\mathrm{P}^{32}$ activity in 3-phosphoglyceric acid (2). It thus seems reasonable to assume that the phosphate on carbon atom 2 of 2,3-DPG has a much higher $\mathrm{P}^{32}$ activity than the phosphate of

${ }^{4}$ It should be pointed out that Bartlett (14), using ionexchange column chromatography, found that the RSA of 2,3-DPG was lower than that of ATP. 


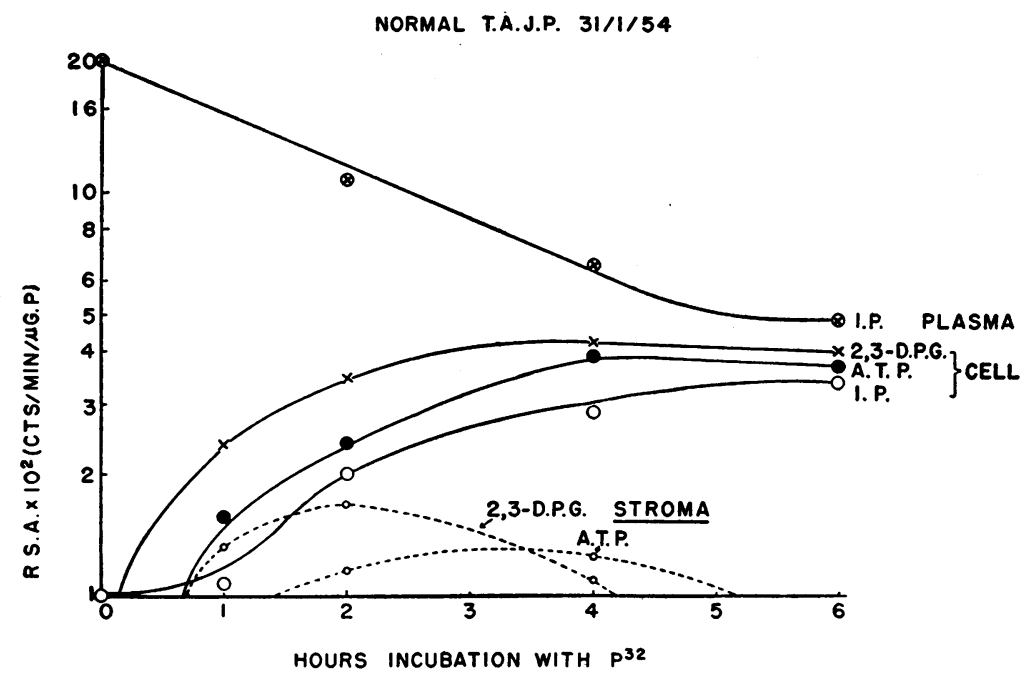

Fig. 1. Relationships of Relative Specific Activities (RSA) of Phosphate Compounds in Normal Red Cells after Incubation with $\mathbf{P}^{32}$-Phosphate

These curves are representative of the results obtained with blood samples from eight normal persons.

carbon atom 3 and that the highly active phosphate of 2,3-DPG is a precursor of the two terminal carbon atoms of ATP.

\section{Studies on HS cells}

The relationships of the intracellular $\mathrm{P}^{82}$-phosphate fractions are altered in red cells from all of the HS patients studied (Figure 2; Table II), although the rate constant for $\mathrm{P}^{82}$ exchange remains within normal limits $(K=0.22 \pm 0.02$ $\mathrm{hr}^{-1}$ ). The difference in $\mathrm{P}^{\mathbf{8 2}}$-phosphate partition manifests itself in most cases in a lower than normal RSA of ATP together with a less marked lowering in the RSA of 2,3-DPG and a higher than normal RSA of IP. In evaluating the data presented in Table II attention should be focused

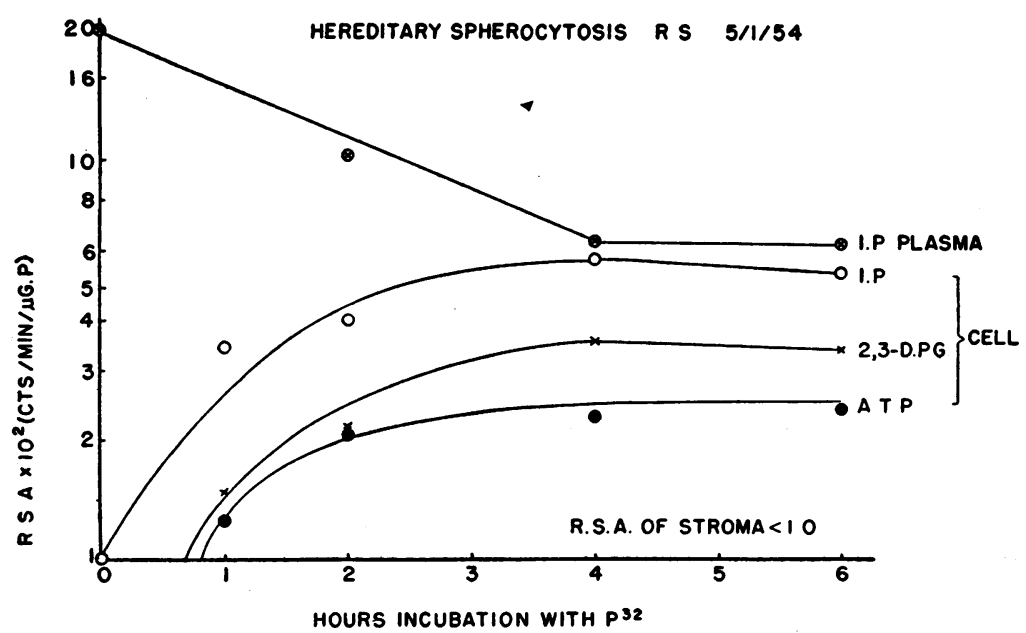

Fig. 2. Relationships of RSA of Phosphate Compounds in HS Red Cenls after Incubation with $P^{2}$-Phosphate

These curves are representative of the results obtained with blood samples from most of the patients studied. 
TABLE II

$R S A$ of various phosphate-containing compounds in red cells from patients with spherocytosis *

\begin{tabular}{|c|c|c|c|c|c|c|c|c|c|}
\hline \multirow{3}{*}{$\begin{array}{l}\text { Case } \\
\text { No. }\end{array}$} & \multicolumn{4}{|c|}{ After $2 \mathrm{hr}$. incubation } & \multicolumn{5}{|c|}{ After $4 \mathrm{hr}$. incubation } \\
\hline & \multicolumn{4}{|c|}{ Intracellular } & \multicolumn{4}{|c|}{ Intracellular } & \multirow{2}{*}{$\frac{\text { Stroma }}{\text { ATP }}$} \\
\hline & 2,3-DPG & ATP & IP & ADP & 2,3-DPG & ATP & IP & $\mathrm{ADP}$ & \\
\hline A $1 \dagger$ & $\begin{array}{c}299 \\
(310)\end{array}$ & $\begin{array}{c}130 \\
(230)\end{array}$ & $\begin{array}{c}339 \\
(270)\end{array}$ & $\begin{array}{l}110 \\
(-)\end{array}$ & $\begin{array}{c}413 \\
(390)\end{array}$ & $\begin{array}{c}180 \\
(366)\end{array}$ & $\begin{array}{c}460 \\
(356)\end{array}$ & $\begin{array}{c}106 \\
(140)\end{array}$ & 45 \\
\hline . $\dagger$ & 250 & 90 & 375 & 74 & 309 & 125 & 454 & 52 & \\
\hline A $2 \dagger$ & $\begin{array}{c}210 \\
(256)\end{array}$ & $\begin{array}{c}197 \\
(230)\end{array}$ & $\begin{array}{c}415 \\
(240)\end{array}$ & $\begin{array}{c}109 \\
(120)\end{array}$ & $\begin{array}{c}390 \\
(457)\end{array}$ & $\begin{array}{c}246 \\
(290)\end{array}$ & $\begin{array}{c}675 \\
(394)\end{array}$ & $\begin{array}{c}194 \\
(211)\end{array}$ & 78 \\
\hline A $3 \dagger$ & $\begin{array}{c}260 \\
(270)\end{array}$ & $\begin{array}{c}139 \\
(240)\end{array}$ & $\begin{array}{c}325 \\
(225)\end{array}$ & $\begin{array}{c}112 \\
(96)\end{array}$ & $\begin{array}{c}400 \\
(416)\end{array}$ & $\begin{array}{c}203 \\
(410)\end{array}$ & $\begin{array}{c}515 \\
(400)\end{array}$ & $\begin{array}{c}177 \\
(134)\end{array}$ & 100 \\
\hline A $4 \dagger$ & $\begin{array}{c}198 \\
(169)\end{array}$ & $\begin{array}{c}154 \\
(101)\end{array}$ & $\begin{array}{c}470 \\
(440)\end{array}$ & $\begin{array}{c}96 \\
(24)\end{array}$ & $\begin{array}{c}333 \\
(104)\end{array}$ & $\begin{array}{l}240 \\
(56)\end{array}$ & $\begin{array}{c}490 \\
(540)\end{array}$ & $\begin{array}{l}124 \\
(50)\end{array}$ & 123 \\
\hline$t$ & $\begin{array}{c}136 \\
(121)\end{array}$ & $\begin{array}{c}116 \\
(100)\end{array}$ & $\begin{array}{c}295 \\
(440)\end{array}$ & $\begin{array}{c}36 \\
(88)\end{array}$ & $\begin{array}{c}272 \\
(244)\end{array}$ & $\begin{array}{c}195 \\
(228)\end{array}$ & $\begin{array}{c}528 \\
(505)\end{array}$ & $\begin{array}{c}109 \\
(147)\end{array}$ & 109 \\
\hline A $5 \dagger$ & $\begin{array}{c}200 \\
(230)\end{array}$ & $\begin{array}{c}140 \\
(108)\end{array}$ & $\begin{array}{c}190 \\
(150)\end{array}$ & $\begin{array}{c}52 \\
(60)\end{array}$ & $\begin{array}{c}280 \ddagger \\
(300)\end{array}$ & $\begin{array}{c}140 \ddagger \\
(175)\end{array}$ & $\begin{array}{r}310 \ddagger \\
(300)\end{array}$ & $\begin{array}{r}60 \ddagger \\
(100)\end{array}$ & 73 \\
\hline A $6 \dagger$ & $\begin{array}{c}159 \\
(254)\end{array}$ & $\begin{array}{c}170 \\
(176)\end{array}$ & $\begin{array}{c}223 \\
(171)\end{array}$ & $\begin{array}{l}136 \\
(94)\end{array}$ & $\begin{array}{c}284 \\
(320)\end{array}$ & $\begin{array}{c}165 \\
(285)\end{array}$ & $\begin{array}{c}310 \\
(225)\end{array}$ & $\begin{array}{c}114 \\
(150)\end{array}$ & 33 \\
\hline \multirow[t]{2}{*}{$t$} & $\begin{array}{c}104 \\
(196)\end{array}$ & $\begin{array}{c}101 \\
(179)\end{array}$ & $\begin{array}{c}219 \\
(129)\end{array}$ & $\begin{array}{c}68 \\
(85)\end{array}$ & $\begin{array}{c}200 \\
(262)\end{array}$ & $\begin{array}{c}143 \\
(259)\end{array}$ & $\begin{array}{c}690 \\
(207)\end{array}$ & $\begin{array}{c}109 \\
(110)\end{array}$ & 27 \\
\hline & $\begin{array}{c}120 \\
(112)\end{array}$ & $\begin{array}{c}155 \\
(185)\end{array}$ & $\begin{array}{c}160 \\
(100)\end{array}$ & $\begin{array}{l}120 \\
(90)\end{array}$ & $\begin{array}{c}190 \\
(195)\end{array}$ & $\begin{array}{c}135 \\
(195)\end{array}$ & $\begin{array}{c}220 \\
(100)\end{array}$ & $\begin{array}{c}150 \\
(96)\end{array}$ & 54 \\
\hline A 7 & $\begin{array}{c}106 \\
(124)\end{array}$ & $\begin{array}{l}100 \\
(70)\end{array}$ & $\begin{array}{l}148 \\
(54)\end{array}$ & $\begin{array}{c}58 \\
(64)\end{array}$ & $\begin{array}{c}198 \\
(234)\end{array}$ & $\begin{array}{c}176 \\
(118)\end{array}$ & $\begin{array}{c}248 \\
(179)\end{array}$ & $\begin{array}{l}160 \\
(84)\end{array}$ & 71 \\
\hline \multirow[t]{2}{*}{ A 8} & $\begin{array}{c}234 \\
(280)\end{array}$ & $\begin{array}{c}200 \\
(228)\end{array}$ & $\begin{array}{c}323 \\
(267)\end{array}$ & $\begin{array}{c}70 \\
(110)\end{array}$ & $\begin{array}{c}465 \\
(425)\end{array}$ & $\begin{array}{c}150 \\
(350)\end{array}$ & $\begin{array}{c}580 \\
(317)\end{array}$ & $(\overline{(180)}$ & 60 \\
\hline & $\begin{array}{c}188 \\
(257)\end{array}$ & $\begin{array}{c}120 \\
(245)\end{array}$ & $\begin{array}{c}282 \\
(382)\end{array}$ & $\begin{array}{c}45 \\
(89)\end{array}$ & $\begin{array}{c}366 \\
(415)\end{array}$ & $\begin{array}{c}215 \\
(226)\end{array}$ & $\begin{array}{c}404 \\
(205)\end{array}$ & $\begin{array}{c}52 \\
(110)\end{array}$ & 84 \\
\hline A 9 & $\begin{array}{c}231 \\
(219)\end{array}$ & $\begin{array}{c}175 \\
(210)\end{array}$ & $\begin{array}{c}386 \\
(200)\end{array}$ & $\begin{array}{c}109 \\
(143)\end{array}$ & $\begin{array}{c}241 \\
(360)\end{array}$ & $\begin{array}{c}230 \\
(234)\end{array}$ & $\begin{array}{c}298 \\
(250)\end{array}$ & $\begin{array}{l}151 \\
(90)\end{array}$ & 46 \\
\hline A 10 & $\begin{array}{c}189 \\
(197)\end{array}$ & $\begin{array}{c}108 \\
(154)\end{array}$ & $\begin{array}{c}298 \\
(136)\end{array}$ & $\begin{array}{c}40 \\
(73)\end{array}$ & $\begin{array}{c}293 \\
(310)\end{array}$ & $\begin{array}{c}75 \\
(274)\end{array}$ & $\begin{array}{c}306 \\
(250)\end{array}$ & $\begin{array}{c}115 \\
(105)\end{array}$ & 93 \\
\hline A 11 & $\begin{array}{c}365 \\
(453)\end{array}$ & $\begin{array}{c}250 \\
(190)\end{array}$ & $\begin{array}{c}327 \\
(450)\end{array}$ & $\begin{array}{c}73 \\
(52)\end{array}$ & $\begin{array}{c}520 \\
(515)\end{array}$ & $\begin{array}{c}270 \\
(323)\end{array}$ & $\begin{array}{c}670 \\
(420)\end{array}$ & $\begin{array}{c}200 \\
(190)\end{array}$ & \\
\hline A 12 & $\begin{array}{c}209 \\
(225)\end{array}$ & $\begin{array}{c}185 \\
(151)\end{array}$ & $\begin{array}{c}235 \\
(240)\end{array}$ & $\begin{array}{c}157 \\
(160)\end{array}$ & $\begin{array}{c}375 \\
(400)\end{array}$ & $\begin{array}{c}300 \\
(287)\end{array}$ & $\begin{array}{c}400 \\
(400)\end{array}$ & $\begin{array}{c}250 \\
(241)\end{array}$ & \\
\hline A 13 & $\begin{array}{c}254 \\
(221)\end{array}$ & $\begin{array}{c}202 \\
(175)\end{array}$ & $\begin{array}{c}241 \\
(289)\end{array}$ & $\begin{array}{c}125 \\
(141)\end{array}$ & $\begin{array}{c}376 \\
(354)\end{array}$ & $\begin{array}{c}297 \\
(241)\end{array}$ & $\begin{array}{c}354 \\
(360)\end{array}$ & $\begin{array}{c}141 \\
(162)\end{array}$ & \\
\hline A 14 & $\begin{array}{c}250 \\
(240)\end{array}$ & $\begin{array}{c}200 \\
(250)\end{array}$ & $\begin{array}{c}220 \\
(180)\end{array}$ & $\begin{array}{c}90 \\
(100)\end{array}$ & $\begin{array}{c}380 \\
(390)\end{array}$ & $\begin{array}{c}300 \\
(275)\end{array}$ & $\begin{array}{c}400 \\
(300)\end{array}$ & $\begin{array}{c}100 \\
(80)\end{array}$ & 94 \\
\hline \multirow[t]{2}{*}{ A 15} & $\begin{array}{c}148 \\
(215)\end{array}$ & $\begin{array}{c}131 \\
(184)\end{array}$ & $\begin{array}{c}354 \\
(153)\end{array}$ & $\begin{array}{c}44 \\
(100)\end{array}$ & $\begin{array}{c}168 \\
(310)\end{array}$ & $\begin{array}{c}140 \\
(255)\end{array}$ & $\begin{array}{c}405 \\
(168)\end{array}$ & $\begin{array}{c}66 \\
(115)\end{array}$ & 21 \\
\hline & $\begin{array}{c}143 \\
(219)\end{array}$ & $\begin{array}{c}108 \\
(119)\end{array}$ & $\begin{array}{c}290 \\
(300)\end{array}$ & $\begin{array}{c}66 \\
(15)\end{array}$ & $\begin{array}{c}196 \\
(212)\end{array}$ & $\begin{array}{c}141 \\
(140)\end{array}$ & $\begin{array}{c}400 \\
(395)\end{array}$ & 二 & 54 \\
\hline B 1 & $\begin{array}{c}246 \\
(300)\end{array}$ & $\begin{array}{c}305 \\
(150)\end{array}$ & $\begin{array}{c}520 \\
(440)\end{array}$ & $\begin{array}{l}150 \\
(96)\end{array}$ & $\begin{array}{c}356 \\
(291)\end{array}$ & $\begin{array}{c}220 \\
(209)\end{array}$ & $\begin{array}{c}512 \\
(490)\end{array}$ & $\overline{(90)}$ & 90 \\
\hline В 2 & $\begin{array}{c}163 \\
(398)\end{array}$ & $\begin{array}{c}176 \\
(193)\end{array}$ & $\begin{array}{c}310 \\
(113)\end{array}$ & $\begin{array}{c}125 \\
(158)\end{array}$ & $\begin{array}{c}266 \\
(437)\end{array}$ & $\begin{array}{c}212 \\
(299)\end{array}$ & $\begin{array}{c}445 \\
(373)\end{array}$ & 177 & 39 \\
\hline B 3 & $\begin{array}{c}172 \\
(200)\end{array}$ & $\begin{array}{c}90 \\
(155)\end{array}$ & $\begin{array}{c}350 \\
(226)\end{array}$ & $\begin{array}{c}20 \\
(150)\end{array}$ & $\begin{array}{c}420 \\
(340)\end{array}$ & $\begin{array}{c}310 \\
(200)\end{array}$ & $\begin{array}{c}500 \\
(340)\end{array}$ & $\begin{array}{c}88 \\
(125)\end{array}$ & \\
\hline \multirow[t]{2}{*}{$\begin{array}{l}\text { Normals } \\
8 \text { persons tested }\end{array}$} & $\begin{array}{r}287 \\
\pm 34\end{array}$ & $\begin{array}{r}236 \\
\pm 38\end{array}$ & $\begin{array}{r}239 \\
\pm 36\end{array}$ & $\begin{array}{r}110 \\
\pm 10\end{array}$ & $\begin{array}{r}404 \\
\pm 20\end{array}$ & $\begin{array}{r}336 \\
\pm 21\end{array}$ & $\begin{array}{r}348 \\
\pm 41\end{array}$ & $\begin{array}{r}151 \\
\pm 13\end{array}$ & $\begin{array}{r}125 \\
\pm 30\end{array}$ \\
\hline & $\begin{array}{l}(295) \\
\pm 15\end{array}$ & $\begin{array}{l}(220) \\
\pm 27\end{array}$ & $\begin{array}{l}(236) \\
\pm 32\end{array}$ & $\begin{array}{l}(114) \\
\pm 10\end{array}$ & $\begin{array}{l}(420) \\
\pm 21\end{array}$ & $\begin{array}{l}(319) \\
\pm 21\end{array}$ & $\begin{array}{l}(359) \\
\pm 36\end{array}$ & $\begin{array}{l}(134) \\
\pm 16\end{array}$ & \\
\hline
\end{tabular}

* All figures in parentheses were obtained with red cells to which adenosine had been added.

† Pre-splenectomy.

Partial clotting of the blood in this specimen after the second hour may have contributed to the low values of RSA of all fractions. 
TABLE III

Mean concentrations of phosphate compounds in red cells from 8 normal persons and $14^{*}$ persons with spherocytosis $\dagger$

\begin{tabular}{lrr}
\hline \hline & Normal & \multicolumn{1}{c}{ Spherocytosis } \\
\hline ATP & $43.2 \pm 5.4$ & $39.2 \pm 6.6$ \\
ADP & $17.0 \pm 4.1$ & $25.9 \pm 1.1$ \\
2,3-DPG & $166.0 \pm 10.1$ & $156.1 \pm 10.4$ \\
IP & $59.4 \pm 9.2$ & $43.3 \pm 6.0$ \\
\hline
\end{tabular}

* Excluding cases A 5, A 12, A 13, A 14.

$\dagger$ All figures represent $\mu \mathrm{g}$. of $\mathrm{P}$ per ml. of packed red cells (mean \pm S.D.).

primarily on the abnormal relationships between the RSA of the $\mathrm{P}^{32}$-labeled compounds rather than on differences in the absolute values of $\mathrm{RSA}$. The absolute values vary as might be expected from a heterogeneous red cell population such as exists in HS cases. The degree of heterogeneity of the red cells in this disease can be expected to vary from patient to patient, and the degree of metabolic abnormality in samples of $\mathrm{HS}$ blood can also be expected to vary considerably.

Analysis of the total quantity of the phosphate compounds present in these abnormal cells reveals nearly normal concentrations of ATP and 2,3-DPG, slightly higher concentration of adenosine diphosphate (ADP) and slightly lower concentration of IP (Table III).

The addition of adenosine to the incubating system of red cells did not alter intracellular $\mathrm{P}^{\mathbf{8 2}}$ partition in normal cells (1-3), but in cells from 10 of the 18 patients investigated, it led to a shift of intracellular relationships towards normal. That is, the RSA of ATP was increased and that of IP reduced (figures in parentheses in Table II). It is of interest that the red cells of all affected members of each family thus far investigated either exhibited the described effect of adenosine on the partitioning of $\mathrm{P}^{32}$ or did not. These findings suggest that the response of the red cells to adenosine may be a genetically determined characteristic by which $\mathrm{HS}$ cases could be subclassified.

It has been mentioned in an earlier report (1) that 2,3-DPG, ATP, and ADP can be isolated from the stroma of red cells and that the RSA of these esters do not parallel those found intracellularly. The $\mathrm{P}^{32}$ activities of the ATP and 2,3DPG fractions separated from the stroma of $\mathrm{HS}$ cells were so much lower than normal in many of the cases that accuracy of the radioactivity measurements was not as great as that of intracellular radioactivity. Since a deficiency in regeneration of ATP in the stroma or an increased activity of stromal ATP-ase might be related to the abnormal shape of HS red cells, an attempt was made to correlate the activities of the ATP fraction of HS stroma with the degree of sphering of the red cells in each case. Accurate estimates of the thickness-diameter ratios of the cells would have been helpful indicators of the degree of sphering (15). Lacking such data, we have taken the concentration of sodium chloride causing 50 per cent hemolysis of freshly drawn and incubated HS cells as a rough index of the degree of sphering (Table I). We have found, however, that more data will be required to show whether or not there is a close correlation between red cell fragility (or shape) and the ATP activity of the stroma.

\section{DISCUSSION}

\section{Abnormalities of $P^{32}$ partitioning in $H S$ cells}

Measurements of incorporation into ATP of $\mathrm{P}^{32}$ derived from extracellular $\mathrm{P}^{32}$-orthophosphate suggest that in the red cells of patients with HS there are abnormalities in the dynamics of intracellular carbohydrate metabolism. Firstly, there is a smaller flux of $\mathrm{P}^{32}$ into ATP of the cell. Because of a nearly normal intracellular pool of ATP (Table III) it is concluded that the rate of $\mathrm{P}^{32}$ incorporation into ATP is slower. This may be associated with the lower potassium content of these cells $(9,16)$. The cation $\mathrm{K}^{+}$activates one of the phosphoferases, pyruvic phosphoferase, which phosphorylates ADP by transferring phosphate from phosphopyruvate to ADP. Secondly, the RSA of orthophosphate is elevated considerably and exceeds that of 2,3-DPG and ATP, in contrast with normal cells.

Although under normal conditions intracellular orthophosphate probably arises largely from the breakdown of ATP, this appears not to be true for the HS cell because the RSA of IP exceeds that of ATP. In view of the data in Table III, it seems probable that this change in the relationship of the RSA of IP to the RSA of ATP, as well as to that of 2,3-DPG, is due to changes in 
the rate of turnover of phosphate rather than to changes in the size of the respective pools. It seems possible that an increased rate of exchange of plasma $\mathrm{P}^{32}$ with intracellular $\mathrm{P}^{32}$, without change in the $\mathrm{P}^{32}$ exchange constant, might explain the altered $\mathrm{P}^{32}$ partition. This could be brought about if a greater proportion of intracellular $\mathrm{P}^{32}$ orthophosphate were incorporated into phosphate esters as compared with the proportion of extracellular $\mathrm{P}^{32}$ orthophosphates on the cell surface. It is also conceivable that a compound having an RSA higher than that of ATP or 2,3-DPG contributes at a greater than normal rate to the intracellular orthophosphate pool. One such compound could be 1,3-DPG from which orthophosphate may be liberated by phosphatase action. There may well be other as yet unknown sources of orthophosphate.

\section{Effect of adenosine on phosphate metabolism of HS cells}

The effect of adenosine in restoring towards normal the intracellular $\mathrm{P}^{32}$ partition may be attributed in part to the conservation of ATP since phosphorylative cleavage of adenosine resulting in the formation of ribose phosphate does not require ATP, as does the phosphorylation of glucose (17). The ribose phosphate(s) thus formed can be metabolized further to yield triose phosphate and hexose phosphates. It is, therefore, possible that adenosine increases the flux of $\mathrm{P}^{32}$ into the intracellular phosphate-containing compounds of $\mathrm{HS}$ cells by providing increased amounts of substrates which may serve as phosphate acceptors or may result in an increased rate of regeneration of ATP. Regeneration of ATP is in part dependent upon an adequate supply of ADP. This must be taken into account in formulating any postulate for the mechanism of action of adenosine on HS cells.

One alternative mechanism which remains as yet without direct supporting evidence may be concerned with the formation of adenylic acid from adenosine, leaving intact the $\mathrm{N}$-riboside linkage of adenosine. Adenylic acid might then give rise to ADP and ATP by the action of an adenylate kinase.

Adenosine may well perform its function at the cell surface where phosphorylative cleavage could occur since the required phosphorylase has been found in the stromal fraction (18) and since the available evidence indicates that adenosine does not enter the red cell.

The $\mathrm{P}^{32}$ activity of ATP was not decreased as significantly in some cases, especially A 12 , A 13 , and $A 14$, as in the other cases but the abnormal relationship of $\mathrm{P}^{32}$-labeled substances was nevertheless demonstrated. The red cells from 7 of the patients in group A (A 4 and A 7 from one family and A 5, A 12, A 13, and A 14 from another and $A 15$ from still another) and from one in group B (B 1) did not exhibit the usual response to incubation with adenosine. The apparent inability of adenosine to shift the intracellular distribution of $\mathrm{P}^{32}$ toward normal in some cases suggests that the necessary phosphorylase may be deficient in the cell stroma although other obvious possibilities exist. This enzyme has recently been demonstrated in stromal extracts of normal red cells following electrophoresis (18). In view of the uniformity of response to adenosine on the part of red cells from all afflicted members of each family studied, it is tempting to postulate that a genetically determined enzyme deficiency or functional inadequacy may be related to the lack of response to adenosine noted in members of certain families. Further genetic, hematologic, and biochemical studies will be needed before the significance of such irregularities can be understood. Such investigations may provide a basis upon which the various types of chronic spherocytosis can be more precisely classified. Somewhat similar changes have been found in the distribution of $\mathrm{P}^{32}$ in the cells from a number of different acquired hemolytic disorders, but only in $\mathrm{HS}$ has the corrective effect of adenosine been observed.

\section{Relationship of metabolic abnormalities of $H S$ cells to hematologic findings}

The low $\mathrm{P}^{32}$ activity found in the stromal ATP fraction of HS cells may throw some light on the mechanism of sphering. Our findings suggest that an adequate rate of regeneration of ATP, and thus an adequate availability of energy-rich phosphate bonds, is necessary for the maintenance 
of the biconcave shape. This may involve the function of certain contractile elements in red cell stroma. As we have suggested elsewhere (2), such a contractile element may resemble myosin, and like myosin might have ATP-ase activity. The demonstration of ATP-ase in red cell stroma (19) supports this view.

It seems likely that the biochemical abnormalities of HS cells are related to the principal hematologic findings and to the role of the spleen in this disease. When sterile defibrinated blood from $\mathrm{HS}$ patients is incubated at body temperature for 24 hours, the red cells undergo more rapid sphering and greater increase in osmotic fragility than do normal red cells $(8,20,21)$. HS cells incubated similarly for 48 hours hemolyze much more readily than normal red cells, but if glucose, mannose, adenosine, or guanosine is added to the HS blood before incubation autohemolysis is markedly reduced $(9,21)$. Some details of these changes have been reported by Selwyn and Dacie (9). During the first 24 hours the cells swell because of acquisition of sodium and water, but during the second 24 hours they lose potassium, shrink, and finally hemolyze. In the opinion of these authors hemolysis during incubation is the result of a degeneration of the cell membrane. Similar changes have been observed in this laboratory. The rapid loss of potassium observed might be related to the high rate of sodium extrusion from HS cells reported by Harris and Prankerd (22). A normal rate of disappearance of glucose in incubated HS blood has been reported by Selwyn and Dacie (9) and has also been demonstrated repeatedly in this laboratory. To our knowledge, however, there are no reported studies on the rate of lactic acid formation in incubated HS blood.

Measurements of spontaneous lysis occurring in incubated blood reveal greater susceptibility to hemolysis of the HS cell with any depletion in the supply of metabolites available for energy production. The various substances tested may afford this cell protection by enabling glycolysis to continue and the potential energy within the cell to be maintained. The channels through which this energy is ultimately directed are multiple and include the control of electro-chemical ionic gradients, maintenance of structure and turnover of lipids of the cell membrane, and possibly other functions, the failure of any of which may result in hemolysis.

\section{Relationship of metabolic abnormalities of $H S$ cells to the mechanism of red cell destruction in vivo}

The changes occurring on in vitro incubation of HS cells may be related to the effects of stagnation and hemoconcentration in the spleen, as first suggested in 1940 by Ham and Castle (23). Selective trapping of $H S$ cells in the spleen has since been demonstrated $(13,20)$, and Gibson and associates (24) have shown that the hematocrit of splenic blood may be as high as 80 per cent. We can therefore postulate that the supply of substrate per cell would be reduced within the spleen, and would be still further depleted by the metabolism of the mass of lymphoid tissue in the splenic pulp. The HS cells trapped within the spleen might then be faced with "relative starvation," a situation similar to that obtaining in the previously cited in vitro experiments. After the splenic trap is removed these cells may survive normally because of continuous access to plasma constituents, despite persistence of the metabolic and structural abnormalities.

\section{SUMMARY}

1. A defect in intracellular glycolysis involving a smaller flux of $\mathrm{P}^{32}$ into ATP and 2,3-DPG with a concurrent increase in the flux into orthophosphate was observed in cells from patients with hereditary spherocytosis. The turnover of $\mathrm{P}^{32}$ of ATP and 2,3-DPG in the stromal fraction tended to be lower than normally found.

2. These abnormalities persist after splenectomy and in most cases were found to be largely restored to normal on incubation of the cells with adenosine. Lack of the corrective effect of adenosine in some cases suggests that the group of patients, now regarded as cases of hereditary spherocytosis, may not be homogeneous.

3. The abnormalities in carbohydrate metabolism have been correlated with the clinical course of the disease, and it is suggested that the susceptibility of the red cells to hemolysis may be due to an inadequate supply or utilization of energy within the cells or stroma in the form of high energy phosphate bonds. 


\section{Addendum}

Recent experiments in this laboratory have revealed that a number of the compounds participating in the oxidative glucose-6-phosphate shunt are labeled by $\mathrm{P}^{32}$ under the experimental conditions described in this paper. It has also been ascertained that $H S$ cells from those patients not responding to adenosine are not deficient in purine $\mathrm{N}$-riboside phosphorylase.

The formation of adenylic acid from extracellular adenosine can now be excluded as an explanation of the effect of adenosine described in this paper, since one of us (T.A.J.P.) has found that adenine, resulting from phosphorolysis of adenosine added to the plasma, does not enter the cell.

Since this manuscript was prepared, we have learned that other workers have found ATP-ase in stroma:

a) Clarkson, E. M., and Maizels, M., Distribution of phosphatases in human erythrocytes. J. Physiol., 1952, 116, 112.

b) Herbert, E., A study of the liberation of orthophosphate from adenosine triphosphate by the stromata of human erythrocytes. Ph.D. Thesis, University of Pennsylvania, 1952.

\section{ACKNOWLEDGMENT}

We wish to thank Mrs. Marion Murphy, Mrs. Pearl S. Miller, and Miss Mary Jane Izzo for their technical assistance.

\section{REFERENCES}

1. Prankerd, T. A. J., and Altman, K. I., Phosphate partition and turnover in human red cells. Nature, 1954, 173, 870.

2. Prankerd, T. A. J., and Altman, K. I., A study of the metabolism of phosphorus in mammalian red cells. Biochem. J., 1954, 58, 622.

3. Prankerd, T. A. J., and Altman, K. I., The effect of adenosine on the phosphate exchange in mammalian red blood cells. Biochem. et Biophys. Acta, 1954, 15, 158.

4. Caldwell, P. C., The separation of the phosphate esters of muscle by paper chromatography. Biochem. J., 1953, 55, 458.

5. Wintrobe, M. M., Clinical Hematology, Third Edition, Philadelphia, Lea and Febiger, 1951, p. 303.

6. Chaplin, H., Jr., and Mollison, P. L., Correction for plasma trapped in the red cell column of the hematocrit. Blood, 1952, 7, 1227.

7. Furth, F. W., Unpublished observations.

8. Young, L. E., Izzo, M. J., and Platzer, R. F., Hereditary spherocytosis. I. Clinical, hematologic and genetic features in 28 cases, with particular reference to the osmotic and mechanical fragility of incubated erythrocytes. Blood, 1951, 6, 1073.
9. Selwyn, J. G., and Dacie, J. V., Autohemolysis and other changes resulting from the incubation in vitro of red cells from patients with congenital hemolytic anemia. Blood, 1954, 9, 414.

10. Evans, R. S., and Duane, R. T., Acquired hemolytic anemia. I. The relation of erythrocyte antibody production to activity of the disease. II. The significance of thrombocytopenia and leukopenia. Blood, 1949, 4, 1196.

11. Thompson, W. P., The splenic lesion in hemolytic jaundice. Bull. Johns Hopkins Hosp., 1932, 51, 365.

12. Dacie, J. V., Familial haemolytic anaemia (acholuric jaundice), with particular reference to changes in fragility produced by splenectomy. Quart. J. Med., 1943, 12, 101.

13. Young, L. E., Platzer, R. F., Ervin, D. M., and Izzo, M. J., Hereditary spherocytosis. II. Observations on the role of the spleen. Blood, 1951, 6, 1099.

14. Bartlett, G. R., Personal communication.

15. Haden, R. L., The volume thickness index of the erythrocyte of man. J. Lab. \& Clin. Med., 1935, 20, 567.

16. Maizels, M., The anion and cation contents of normal and anaemic bloods. Biochem. J., 1936, 30, 821.

17. Dische, Z., Synthesis of hexosemono- and diphosphate from adenosine and ribose-5-phosphate in human blood in Symposium on Phosphorus Metabolism. Baltimore, Johns Hopkins Press, 1951.

18. Prankerd, T. A. J., and Altman, K. L., Riboside phosphorylase in human red cell stroma. To be published.

19. Garzó, T., Ullmann, A., and Straub, F. B., Die Adenosintriphosphatase der roten Blutkörperchen. Acta physiol. Hung., 1952, 3, 513.

20. Emerson, C. P., Jr., Shen, S. C., Ham, T. H., and Castle, W. B., The mechanism of blood destruction in congenital hemolytic jaundice. J. Clin. Invest., 1947, 26, 1180.

21. Izzo, M. J., Altman, K. I., Swisher, S. N., and Young, L. E., Unpublished observations.

22. Harris, E. J., and Prankerd, T. A. J., The rate of sodium extrusion from human erythrocytes. J. Physiol., 1953, 121, 470.

23. Ham, T. H., and Castle, W. B., Relation of increased hypotonic fragility and of erythrostasis to the mechanism of hemolysis in certain anemias. Tr. A. Am. Physicians, 1940, 55, 127.

24. Gibson, J. G., 2nd., Seligman, A. M., Peacock, W. C., Aub, J. C., Fine, J., and Evans, R. D., The distribution of red cells and plasma in large and minute vessels of the normal dog, determined by radioactive isotopes of iron and iodine. $\mathrm{J}$. Clin. Invest., 1946, 25, 848. 